\title{
Investigation of Thermal, Structural and Electrical Properties of $\mathrm{LaMnO}_{3}$-Sigma
}

\author{
Kassahun Lewetegn Damena \\ Physics, Arba Minch University, ArbaMinch, Ethiopia \\ Email address: \\ klewetegn@gmail.com, kassahun.lewetegn@amu.edu.et \\ To cite this article: \\ Kassahun Lewetegn Damena. Investigation of Thermal, Structural and Electrical Properties of $\mathrm{LaMnO}_{3}$-Sigma. American Journal of \\ Nanosciences. Vol. 5, No. 4, 2019, pp. 48-55. doi: 10.11648/j.ajn.20190504.14
}

Received: October 24, 2019; Accepted: November 18, 2019; Published: November 26, 2019

\begin{abstract}
LaMnO}_{3}$ is one of the most intensively studied cathode materials for solid oxide fuel cell (SOFC). In the present study, $\mathrm{LaMnO}_{3-\delta}$, cathode materials were synthesized by combustion method. The properties of synthesized materials like thermal, structural, electrical and electrochemical were investigated. Thermogravimetric analysis (TGA/DTA) analysis confirms that the calcination temperature $\left(1000^{\circ} \mathrm{C}\right)$ is the appropriate temperature for the preparation of the materials using $\mathrm{La}\left(\mathrm{NO}_{3}\right)_{3} \cdot 6 \mathrm{H}_{2} \mathrm{O}, \mathrm{MnSO}_{4} \cdot \mathrm{H}_{2} \mathrm{O}, \mathrm{Co}\left(\mathrm{NO}_{3}\right)_{2} \cdot 6 \mathrm{H}_{2} \mathrm{O}, \mathrm{Fe}\left(\mathrm{NO}_{3}\right)_{3} \cdot 9 \mathrm{H}_{2} \mathrm{O}$ and $\mathrm{C}_{6} \mathrm{H}_{8} \mathrm{O}_{7} \cdot \mathrm{H}_{2} \mathrm{O}$ precursors. The X-ray powder diffraction (XRD) results of the materials reveal the formation of the hexagonal structure with $\mathrm{R} 3 \mathrm{C}$ space group Fd3m. The scanning electron microscope (SEM) characterization shows that the prepared samples have slightly porous structure with agglomerated particles. The energy dispersive spectroscopy (EDS) analysis is also confirms the presence of $\mathrm{La}, \mathrm{Mn}$ and $\mathrm{O}$ elements in all synthesized materials. From the fourier transform infrared spectroscopy (FTIR) analysis, the most significant absorption bands located at $1629.8 \mathrm{~cm}^{1}$ and $589.9 \mathrm{~cm}^{1}$ wave numbers are identified. The room temperature conductivity of the sample is found to be $6.3 \times 10^{-3}$ for $\mathrm{LaMnO}_{3}$ cathode material. From the dielectric constant $\varepsilon^{\prime}$ as a function of frequency observed that value of $\varepsilon^{\prime}$ maximum at lower frequencies and it begins to drop and becomes constant at higher frequencies.
\end{abstract}

Keywords: Perovskites, SOFC, Cathode Materials

\section{Introduction}

A major concern of international community is the requirement of energy to an increasing demand under the constraints of a limited fossil fuel supply. The development of energy generation methods that are not limited to fuel supply has, therefore, been widely investigated for many years. The urgency of such research has further increased since the environmental issues associated with fossil fuel combustion (global warming, ocean acidification, smog, low air quality) have become well recognized [1, 2].

One solution to this energy challenge is the hydrogen powered fuel cell. This cell operates on a potentially limitless supply of fuel through different method while producing water and heat as a byproduct of the electrochemical reaction that generates electricity as can be seen in equation 1 [3].

$$
\frac{1}{2} \mathrm{O}_{2}+\mathrm{H}_{2} \rightarrow \mathrm{H}_{2} \mathrm{O}+\text { Heat }+ \text { Electricity }
$$

There are different types of fuel cells and they are named according to the material used in the electrolyte. These types are alkaline fuel cell (AFC), phosphoric acid fuel cell (PAFC), polymeric electrolyte membrane fuel cell (PEMFC), molten carbonate fuel cell (MCFC), and solid oxide fuel cell (SOFC). In addition to the above category fuel cell also differ in other important aspects such as efficiency and operating temperature [4].

Solid oxide fuel cell (SOFC) is a type of fuel cell which consists of a perovskite structure. The above material structure is widely applied and studied. Except for sealant, all other components of the SOFC can potentially consist of perovskite ceramics. The most common materials found in the single SOFC configuration are Yittra Stabilized Zirconia (YSZ) in the electrolyte, Ni/YSZ cement in the anode and Strontium doped lanthanum manganite (LSM) in the cathode. The cathode is the most common material in which reduction takes place. According to the outcome of different research the composition of the material, 
synthesis method and fabrication have significant impact on the cathode material of SOFC. In most cases, cathode is composed of a perovskite material [4]. Therefore, this study focuses only on cathode perovskite material.

This research work focuses on a mixture of different oxides of manganese which crystallize in perovskite structure called manganites. Manganites have a broad stoichiometric formula of $\mathrm{ABO}_{3 \pm \delta}$, where $\mathrm{A}$ is lanthanide element and $\mathrm{B}$ is manganese. This also includes the ability to generate an exact or no oxygen stoichiometry. One of the main characteristics of manganites perovskites compared with other families of oxides in the wide variety of substitutions in its crystal structure. The lanthanides are among the 25 elements which can occupy the position at A sites. On the other hand, apart from the manganese, almost 50 different elements can occupy the B-site [5].

Manganite compounds crystallize in the structure $\mathrm{ABO}_{3}$ perovskites can have an ideal cubic structure of $\mathrm{Pm} 3 \mathrm{~m}$ space group, orthorhombic Pbnm space group or rhombohedra $\mathrm{R} 3 \mathrm{CH}$ space group [6].

The stoichiometry with the corresponding valance states to manganite is $\mathrm{A}^{+3} \mathrm{~B}^{+3} \mathrm{O}_{3}{ }^{-2}$ with a body centered (BCC) cubic unit cell whose center sits the $\mathrm{A}^{+3}$ cation that is usually the largest one; $\mathrm{B}^{+3}$ cations occupy the eight apex of the cell and $\mathrm{O}^{-2}$ an ions occupy the mid points between cations and in the middle of the edges of the bcc cell [7].

The materials used in SOFC must satisfy many requirements in terms of electrochemical properties. Besides, chemical and physical compatibility must exist between the materials for each component. As SOFC runs in high temperature, a chemical decomposition or a chemical reaction can't occur during its operation and the chosen materials must have a similar thermal expansion coefficient in order to avoid the formation of cracks during thermal cycling. Perovskite oxides display special attention due to their superior electrical, magnetic, catalytic and superconductive properties that can be an advantage to technological and basic materials science investigations [8].

This work investigates $\mathrm{LaMnO}_{3-\delta}$ perovskite, and the primary objectives are on the synthesis of the advanced ceramic perovskites nano powder using citric acid combustion approach and characterization using different physical and thermal techniques. Among the different synthesis methods, the reason for the selection of this method is that it is characterized by fast heating rates; high temperatures and short reaction times [9]. Thermal decomposition behavior of the compounds were investigated by thermal analysis method. The crystalline phases were developed on heat treatment and the structures of all compounds were studied by XRD and FTIR. Morphology of the powders was characterized by SEM. The electrical and electrochemical properties were conducted using complex impedance spectroscopy (CIS).

\section{Method}

\subsection{Experimental Method of Synthesis}

$\mathrm{LaMnO}_{3-\delta}$ perovskites was synthesized by combustion synthesis method using nitrate salts as starting materials and $\mathrm{C}_{6} \mathrm{H}_{8} \mathrm{O}_{7} \cdot \mathrm{H}_{2} \mathrm{O}$ as chelating agent. Stoichiometric amounts of $\mathrm{La}\left(\mathrm{NO}_{3}\right)_{3} \cdot 6 \mathrm{H}_{2} \mathrm{O}$ and $\mathrm{Mn}\left(\mathrm{NO}_{3}\right)_{3} \cdot 6 \mathrm{H}_{2} \mathrm{O}$ was dissolved in some amount of deionized water and mixed together. The mixed metal nitrate solution then added to the citric acid solution in 1:2 molar ratios. Then the solution was placed on magnetic stirrer making the stirrer switch on unlike the heat which is switched off. The stirring procedure without applying heat carried on for one hour and fourteen minutes.

After that, aqueous ammonia solution was added drop wise to the mixed solution on heating condition $70^{\circ} \mathrm{C}$ under constant stirring using magnetic stirrer until the $\mathrm{pH}$ of the solution maintains about 7 .

The mixed solution with $\mathrm{pH} 7$ was constantly stirred by magnetic stirrer on a hot plate at $80^{\circ} \mathrm{C}$ for about 12 hours in the water bath and stirred continuously to obtain a dark brown gel and combustion takes place. Then after it completely burnt out and form a powder. Further, the obtained Powder was grounded for one hour using get mortar.

The calcinations were carried at a temperature of $1000^{\circ} \mathrm{C}$ for five hour to obtain composite oxide powder. The various steps involved in combustion method for synthesis of cathode materials are shown in the flow chart of Figure 1 below.

\subsection{Pellet Preparation}

An ionic, electronic and dielectric property of all synthesized materials was carried out using complex impedance spectroscopy. For this purpose, calcined fine powder was prepared. The preparation process started after combustion. After the final result of combustion the combusted compound placed in a furnace. Applying $1000^{\circ} \mathrm{C}$ for five hour, the furnace cooled down and using get mortar the result was grounded. Then, polyvinyl alcohol (PVA) was used as a binder and it was released in burning during high temperature sintering to prepare the pellet. After this entire step, the final result was cold pressed in to circular disc shaped pellet at a pressure of 5 tons in a stainless-steel dye set using a hydraulic press. After cold pressed the pellets was sintered at $1000^{\circ} \mathrm{C}$ for $4 \mathrm{~h}$ in an alumina crucible in air atmosphere followed by slow cooling process. Subsequently, the pellet was polished by a fine emery paper to make their faces smooth and parallel. The pellets was finally coated with high purity conductive silver paint and dried at $100^{\circ} \mathrm{C}$ for 30 minutes to remove the moisture. 


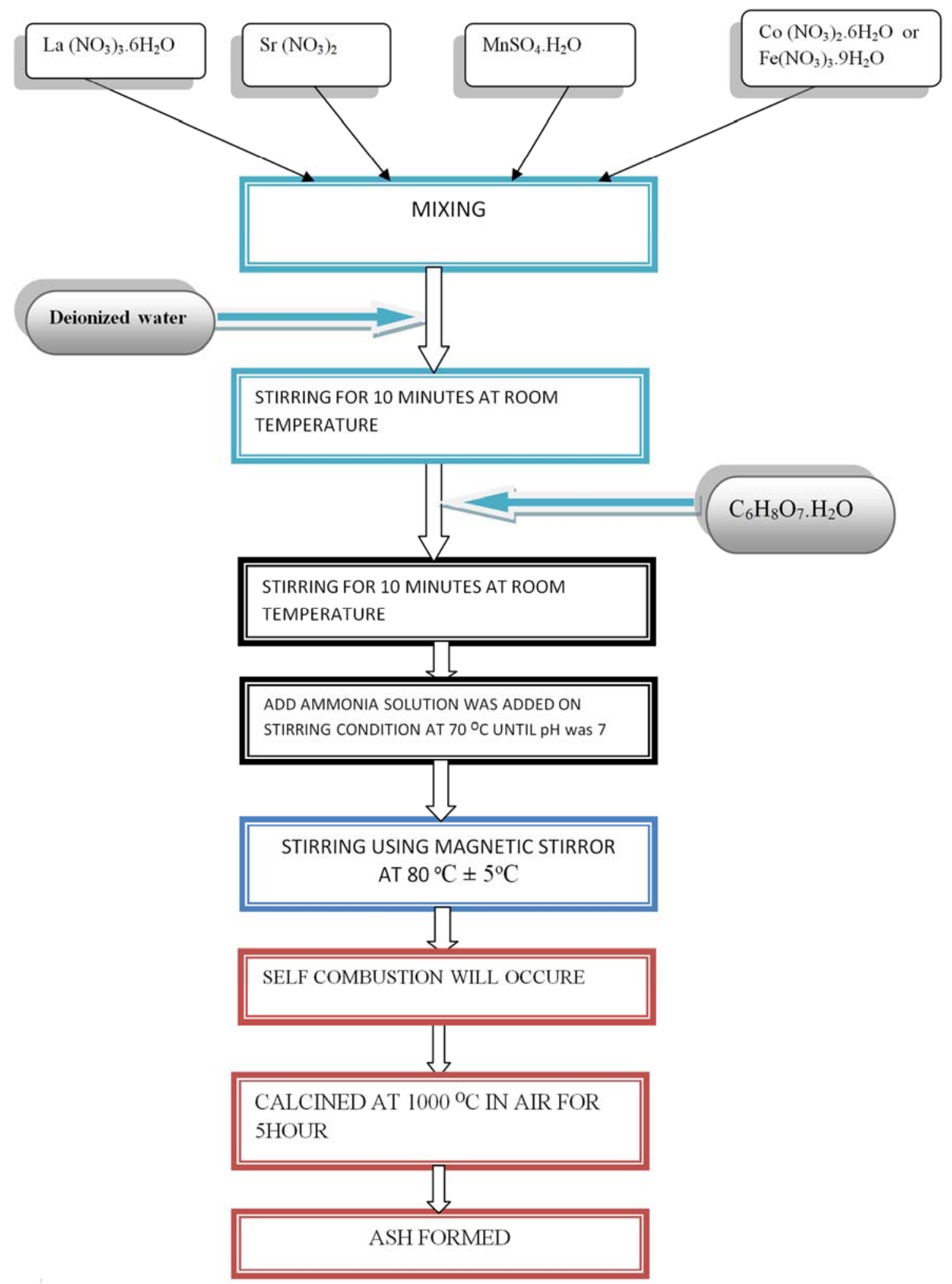

Figure 1. Schematic diagram powder preparation process.

\section{Results and Discussion}

\subsection{Thermal Analysis}

In order to investigate the thermal behavior of the LSM samples, around $15 \mathrm{mg}$ of the mixture of $\mathrm{La}\left(\mathrm{NO}_{3}\right)_{3} \cdot 6 \mathrm{H}_{2} \mathrm{O}$,
$\mathrm{MnSO}_{4} \cdot \mathrm{H}_{2} \mathrm{O}$ and $\mathrm{C}_{6} \mathrm{H}_{8} \mathrm{O}_{7} \cdot \mathrm{H}_{2} \mathrm{O}$ precursors were used. The precursors were heated over the temperature range between room temperature and $1100^{\circ} \mathrm{C}$ under nitrogen atmosphere. The obtained curves are represented in Figures 2. As it can be seen in the figure, thermal decomposition takes place in different stages, depending on the decomposition behavior of 
each precursor and the significant weight loss regions as well as the stable phase formation region are also identified.

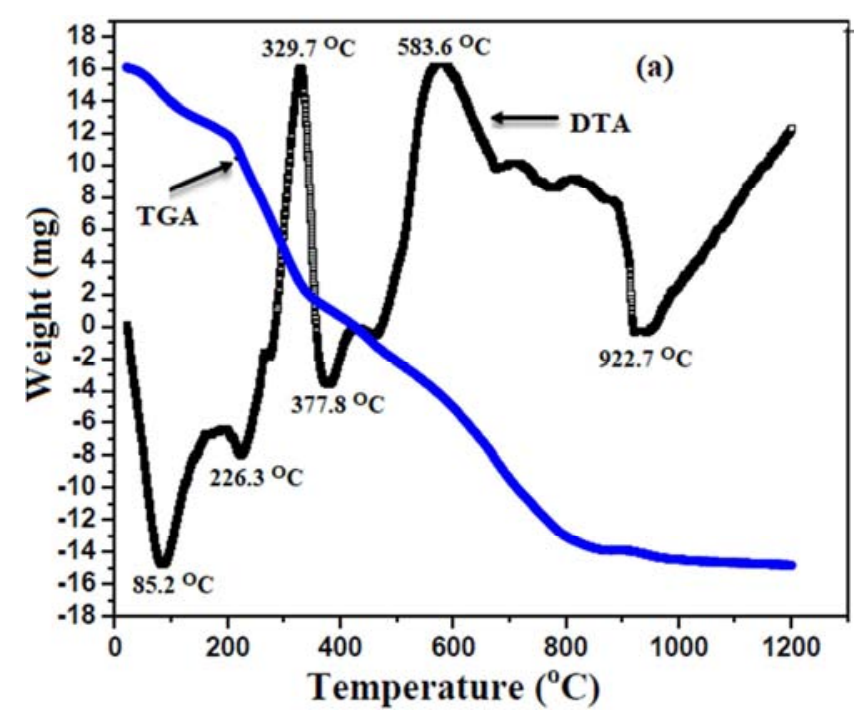

Figure 2. TGA/DTA study of $\mathrm{LaMnO}_{3}$.

Figure 2 shows the TGA/DTA behavior of the mixture of $\mathrm{La}\left(\mathrm{NO}_{3}\right)_{3} \cdot 6 \mathrm{H}_{2} \mathrm{O}, \mathrm{MnSO}_{4} \cdot \mathrm{H}_{2} \mathrm{O}$ and $\mathrm{C}_{6} \mathrm{H}_{8} \mathrm{O}_{7} \cdot \mathrm{H}_{2} \mathrm{O}$ precursors to form $\mathrm{LaMnO}_{3}$ cathode material. It is observed that the first endothermic peak is appeared at $85.2^{\circ} \mathrm{C}$ with respective weight loss of $3.13 \%$ due to the moisture absorbed during storage. Further, the DTA curve observed at $223.6^{\circ} \mathrm{C}$ which is accompanied by a weight loss of $11.4 \%$ refers to the loss of the water used during synthesis procedure. The other DTA peak at $329.7^{\circ} \mathrm{C}$ intended by a weight loss of $32.7 \%$ refers to the decomposition of citric acid and followed by the endothermic peak at $377.8^{\circ} \mathrm{C}$ due to removal of water produced from the decomposition citric acid. Further, the exothermic DTA peak formed at $583.6^{\circ} \mathrm{C}$ refers to the starting point for decomposition of nitrate precursor to form the compound. Between $450^{\circ} \mathrm{C}$ and $800^{\circ} \mathrm{C}$, some exothermic peaks are observed in the DTA curve. These exothermic peaks are probably associated with the decomposition of the nitrates, sulphates and other remaining organic residuals mainly fuels that was not burn during fast combustion reaction. The endothermic peak observed at $922.7^{\circ} \mathrm{C}$ may be due to complete dissociation of carbonates produced during combustion and formation of $\mathrm{LaMnO}_{3}$ phase.At higher temperatures, the TGA curve becomes more flattened, indicating the stable phase formation of $\mathrm{LaMnO}_{3}$. This indicates that $1000^{\circ} \mathrm{C}$ temperature can be used for preparation of $\mathrm{LaMnO}_{3}$ material using $\mathrm{La}\left(\mathrm{NO}_{3}\right)_{3} \cdot 6 \mathrm{H}_{2} \mathrm{O}, \mathrm{MnSO}_{4} \cdot \mathrm{H}_{2} \mathrm{O}$ and $\mathrm{C}_{6} \mathrm{H}_{8} \mathrm{O}_{7} \cdot \mathrm{H}_{2} \mathrm{O}$ precursors. Moreover, the total loss of sample weight up to $1100^{\circ} \mathrm{C}$ is $68.5 \%$.

\subsection{Structural Analysis}

For further explanation of $\mathrm{LaMnO}_{3}$ in case of structural analysis two materials were synthesized by substitution on the two different sites that is the A-site and B-site. Therefore, the XRD patterns of $\mathrm{LaMnO}_{3}, \mathrm{La}_{0.8} \mathrm{Sr}_{0.1} \mathrm{Co}_{0.1} \mathrm{MnO}_{3}$ and $\mathrm{La}_{0.8} \mathrm{Sr}_{0.1} \mathrm{Fe}_{0.1} \mathrm{MnO}_{3}$ cathode materials synthesized by sol-gel combustion method heated at $1000^{\circ} \mathrm{C}$ for 4 hours in air are shown in Figure 3. It is observed that all the diffraction peaks are strong and sharp, indicating highly crystalline of the cathode materials.

The diffraction peaks which are indexed as (110), (020), (200), (022), (202), (220), (130), (312) and (204) represent of the perovskite phase with hexagonal structure with space group of R-3C [6], which is in line with Joint Committee on Powder Diffraction Standards (JCPDS) card number 00-0511515. However, additional peaks for Co and Fe substituted samples are appeared, which correspond to the impurity for $\mathrm{LaMnO}_{3}$ compound. However, as compared the XRD of the three samples, the diffraction peaks of $\mathrm{La}_{0.8} \mathrm{Sr}_{0.1} \mathrm{Co}_{0.1} \mathrm{MnO}_{3}$ and $\mathrm{La}_{0.8} \mathrm{Sr}_{0.1} \mathrm{Fe}_{0.1} \mathrm{MnO}_{3}$ samples are shifted slightly towards higher angles. This indicates the fact that the substitution of $\mathrm{Co}^{2+}, \mathrm{Sr}^{2+}$ and $\mathrm{Fe}^{3+}$ cations for $\mathrm{La}$ cations has led to the decrease in the crystal size of $\mathrm{LaMnO}_{3}$.

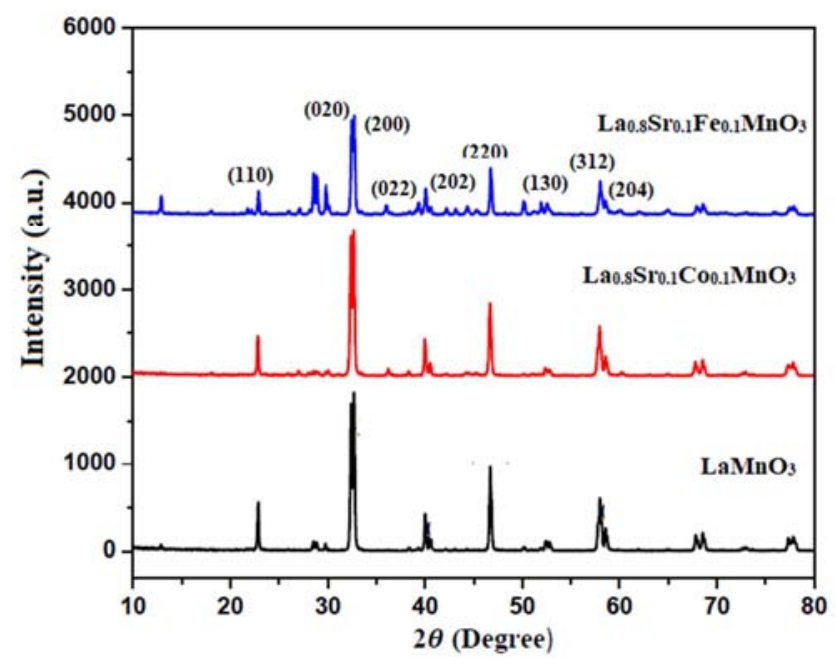

Figure 3. XRD patterns of the synthesized samples.

The lattice parameters, the unit cell volumes and the crystal sizes of each sample were calculated from XRD patterns, and the obtained results are summarized in Table 1. It is found that the lattice parameters, unite cell volumes and crystal sizes of $\mathrm{LaMnO}_{3}$ material are slightly larger than that of $\mathrm{La}_{0.8} \mathrm{Sr}_{0.1} \mathrm{Co}_{0.1} \mathrm{MnO}_{3-\delta}$ and $\mathrm{La}_{0.8} \mathrm{Sr}_{0.1} \mathrm{Fe}_{0.1} \mathrm{MnO}_{3-\delta}$ materials. This is associated with the ionic radius differences of the substituted cations. As compared the substituted materials, Co substituted $\mathrm{La}_{0.8} \mathrm{Sr}_{0.1} \mathrm{Co}_{0.1} \mathrm{MnO}_{3}$ has larger lattice parameter $(\mathrm{a}=7.2476 \AA$ and $\mathrm{c}=7.8201 \AA)$, unite cell volume $\left(355.7378 \AA^{3}\right)$ and crystal size (507.63nm) than $\mathrm{Fe}$ substituted $\mathrm{La}_{0.8} \mathrm{Sr}_{0.1} \mathrm{Fe}_{0.1} \mathrm{MnO}_{3}$-material. This behavior can be understood from the ionic radii that is the ionic radius of $\mathrm{Co}^{2+}(0.79 \AA)$ [9] is larger than that of $\mathrm{Fe}^{3+}(0.64 \AA)$ [10]. The variation of lattice parameters and shift the diffractions line, suggest the incorporation of the dopants in the lattice of both cathodes. 
Table 1. Lattice constant, unite cell volume and crystal size of synthesized samples.

\begin{tabular}{lllll}
\hline \multirow{2}{*}{ Samples } & \multicolumn{2}{l}{ Lattice Constants $(\AA)$} & UniteCellVolumeV (nm3) & \multirow{2}{*}{ CrystalSizefrom (200) $(\AA)$} \\
\cline { 2 - 3 } & $\mathbf{a}$ & c & 355.6097 & 507.63 \\
$\mathrm{LaMnO}_{3}$ & 7.2439 & 7.8252 & 355.7378 & 408.16 \\
$\mathrm{La}_{0.8} \mathrm{Sr}_{0.1} \mathrm{Co}_{0.1} \mathrm{MnO}_{3}$ & 7.2476 & 7.8201 & 353.9521 & 157.63 \\
$\mathrm{La}_{0.8} \mathrm{Sr}_{0.1} \mathrm{Fe}_{0.1} \mathrm{MnO}_{3 \mathrm{~d}}$ & 7.2348 & 7.8305 & \\
\hline
\end{tabular}

\subsection{SEM and EDS Study}

To study the morphology and the grain size distributions of $\mathrm{LaMnO}_{3-\delta}$ cathode in the form of powder, the sample is characterized by using scanning electron microscope. Figure 4 shows SEM images of all samples synthesized by sol-gel combustion method at calcination temperature of $1000^{\circ} \mathrm{C}$. It is observed that the synthesized samples have fairly uniform grain size distribution, indicating well developed crystallinity. This is consistent with well-defined diffraction peaks observed from XRD patterns. It is also observed that all the prepared samples have porous structure and they have slightly agglomerated particles. The porous structure of the cathode material is important for the insertion and deinsertion of cations during charging and discharging process.

The morphology of $\mathrm{LaMnO}_{3}$ is more compact as compared to the morphology of the materials found by substitution of elements with ionic radius larger than the elements in the Asite and B-site of the first compound.

The elemental analysis of $\mathrm{LaMnO}_{3}$ of cathode materials was analyzed by energy dispersive spectroscopy (EDS). As shown in the figure 4 , all the synthesized materials show the presence of $\mathrm{La}, \mathrm{Mn}$, and $\mathrm{O}$. No other elements are detected in the investigated manganite, which indicates the purity of the synthesized products. This is consistent with the result obtained in the XRD patterns.
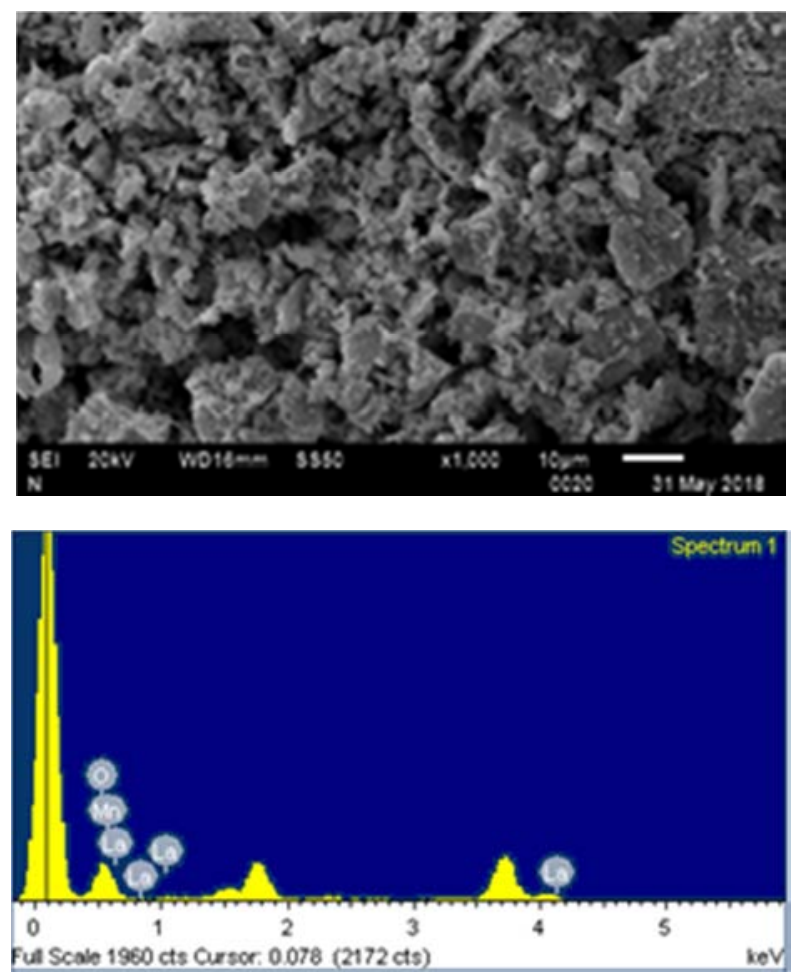

Figure 4. SEM and EDS images of $\mathrm{LaMnO}_{3}$ of cathode materials.

\subsection{FT-IR Spectroscopy Study}

Figure 5 shows the room temperature FT-IR spectra of the synthesized $\mathrm{LaMnO}_{3}$ and $\mathrm{La}_{0.8} \mathrm{Sr}_{0.1}(\mathrm{Co}, \mathrm{Fe})_{0.1} \mathrm{MnO}_{3}$ cathode materials in the wavelength range of 350 to $2500 \mathrm{~cm}^{-1}$. As it is observed in the Figure 5, different similar strong absorption bands are identified at different wave number regions. The most significant absorption bands are located between 712.6 and $484.4 \mathrm{~cm}^{-1}$ wave numbers. These bands are assigned to stretching vibrations due to interactions between the cations and oxygen in the synthesized compounds. This indicates the formation of the perovskite-type structures [11].

The band appeared at wavenumber $568.3 \mathrm{~cm}^{-1}$ is responsible for the formation of $\mathrm{LaMnO}_{3}$ compound, which attributed to stretching vibration of $\mathrm{Mn}-\mathrm{O}$ band of $\mathrm{MnO}_{6}$ octahedron. As compared with $\mathrm{LaMnO}_{3}$, the absorption of Sr, $\mathrm{Co}$ and $\mathrm{Fe}$ substituted materials are shifted slightly towards to higher wave number regions. This indicates that the substitution of these cations into $\mathrm{LaMnO}_{3}$ has led to the decrease in octahedral site radius. This result is in good agreement with lower lattice parameters and unit cell volume calculated from the XRD patterns. On the other hand, peaks observed at around 1629.8 and $2365.6 \mathrm{~cm}^{-1}$ are attributed to the deformation mode of absorbed molecular water of the carrier $\mathrm{KBr}\left(\mathrm{H}_{2} \mathrm{O}\right) \mathrm{n}$ and $\mathrm{CO}_{2}$, respectively [12].

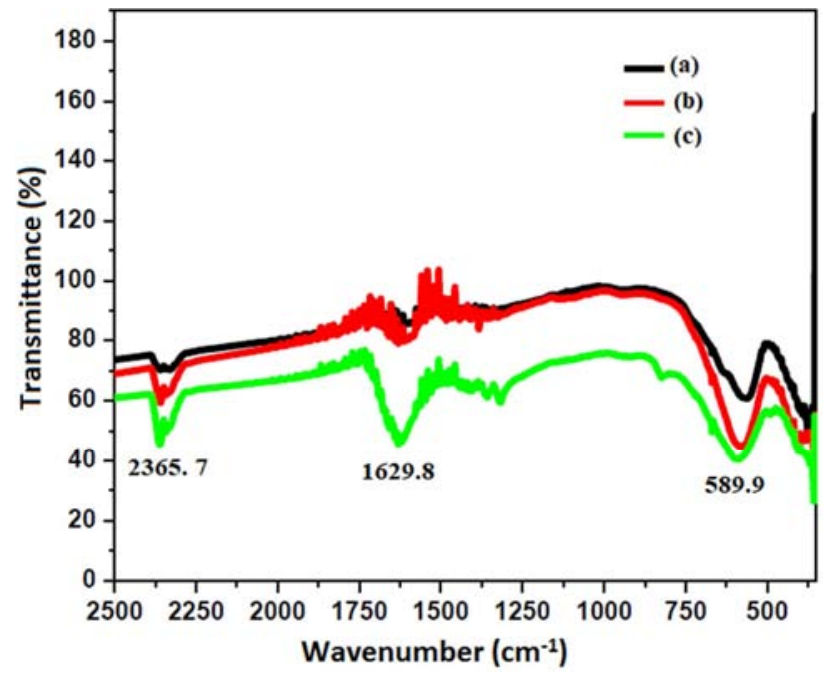

Figure 5. FT-IR spectra of a) $\mathrm{LaMnO}_{3}$ b) $\mathrm{La}_{0.8} \mathrm{Sr}_{0.1} \mathrm{Co}_{0.1 \mathrm{I}} \mathrm{MnO}$. c) $\mathrm{La}_{0.8} \mathrm{Sr}_{0.1} \mathrm{Fe}_{0.1} \mathrm{MnO}_{3}$ of cathode materials.

Since the number of absorption peaks is related to the number of vibrational freedom of the molecule. For the sample shown in the above figure, the significant numbers of absorption peaks are two. The differences in the three compounds lie on the amount of transmittance. The amount of transmittance of $\mathrm{LaMnO}_{3}$ is less shallow than 
$\mathrm{La}_{0.8} \mathrm{Sr}_{0.1} \mathrm{Co}_{0.1} \mathrm{MnO}_{3}$ where as the amount of transmittance of $\mathrm{La} 0.8 \mathrm{Sr} 0.1 \mathrm{Fe} 0.1 \mathrm{MnO}_{3}$ is shallower than the two compounds

\subsection{Electrochemical Impedance Spectroscopy Analysis}

Impedance spectra can be plotted in two ways: in the Nyquist representation where the negative imaginary part of the impedance, $Z$ ", is plotted versus the real part of the impedance, $Z$ or in the Bode representation where the absolute impedance, $|\mathrm{Z}|$, as well as the phase shift is plotted versus the angular frequency. Even if both representations contain, in principle, the same information and can be transformed in to each other, for this research work Nyquist plot was used to see the relation between real and imaginary impedance.

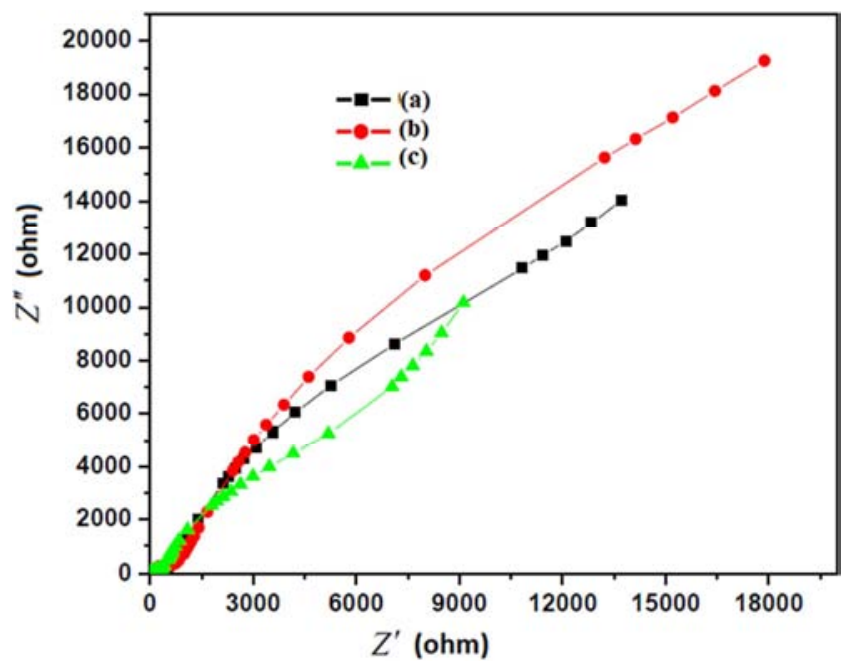

Figure 6. Cole-Cole plots for a) $\mathrm{LaMnO}_{3}$ b) $\mathrm{La}_{0.8} \mathrm{Sr}_{0.1} \mathrm{Co}_{0.1} \mathrm{MnO}_{3-\delta}$ c) $\mathrm{La}_{0.8} \mathrm{Sr}_{0.1} \mathrm{Fe}_{0.1} \mathrm{MnO}_{3-\delta}$ of cathode materials.

In Figure 6 shown above the real versus imaginary impedance for three compounds show single arc, which indicates that the electrical process contribution is from bulk materials (grain interior), which can be modeled as an equivalent circuit comprising of a parallel combination of bulk resistance and bulk capacitance. This can be seen in other work that one arc can be modeled as an equivalent circuit comprising of a parallel combination of bulk resistance and bulk capacitance [13]. The figure 6 starts from zero ohms for both real and imaginary line and goes to $195000 \mathrm{ohm}$ for real and $21000 \mathrm{ohm}$ for imaginary. The figure indicates that there is a direct relationship between real and imaginary for the three compounds. The imaginary value of $\mathrm{La}_{0.8} \mathrm{Sr}_{0.1} \mathrm{Co}_{0.1} \mathrm{MnO}_{3-\delta}$ greater than $\mathrm{LaMnO}_{3}$ and $\mathrm{LaMnO}_{3}$ greater than $\mathrm{La}_{0.8} \mathrm{Sr}_{0.1} \mathrm{Fe}_{0.1} \mathrm{MnO}_{3-\delta}$ on the same value real impedance $6000 \mathrm{ohm}$. This difference is not the same at higher value of real impedance. Towards the left below 1500 ohm of real impedance a small arc is expected. These arcs are usually related to the interfacial resistance between an electrolyte and a cathode (grain boundary conduction or charge transfer) at an intermediate frequency and the oxygen reduction reaction at the cathode surface (diffusion or concentration polarization) at a low frequency [14].

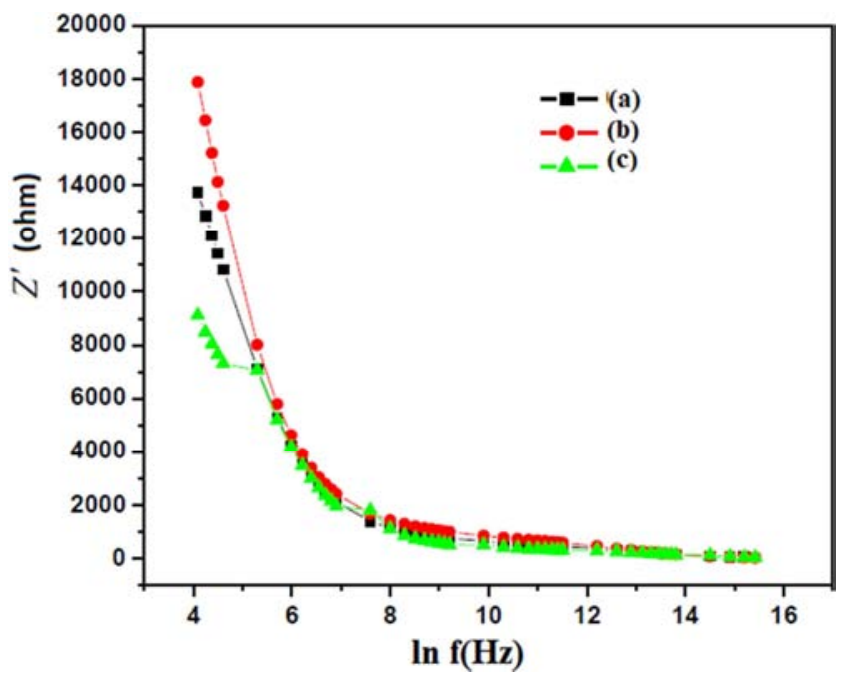

Figure 7. Real impendence ( $\left.Z^{\prime}\right)$ versus $\ln (f)$ for a) $\mathrm{LaMnO}_{3}$ b) $\mathrm{La}_{0.8} \mathrm{Sr}_{0.1} \mathrm{Co}_{0.1} \mathrm{MnO}_{3} \mathrm{c}$ ) $\mathrm{La}_{0.8} \mathrm{Sr}_{0.1} \mathrm{Fe}_{0.1} \mathrm{MnO}_{3}$ of cathode materials.

According to Figure7 the real impedance value decreases with increasing the logarithm of frequency. Below $5 \mathrm{~Hz}$ of $\ln (\mathrm{f})$ the real impedance of $\mathrm{LaMnO}_{3}$ lies between the other two compounds found by substitution process. The real impedance of $\mathrm{LaMnO}_{3}$ decreases as the value of $\ln (\mathrm{f})$ increase. The decrease proceeds with no fluctuation like that of $\mathrm{La}_{0.8} \mathrm{Sr}_{0.1} \mathrm{Fe}_{0.1} \mathrm{MnO}_{3}$ cathode material. Above $6 \mathrm{~Hz}$ of $\ln (\mathrm{f})$ the compounds found by element substitution on A-site and B-site of $\mathrm{LaMnO}_{3}$ show a similar decrease in the amount of real impedance. Above the logarithmic frequency of twelve the real impedance approaches zero for the three synthesized compounds.

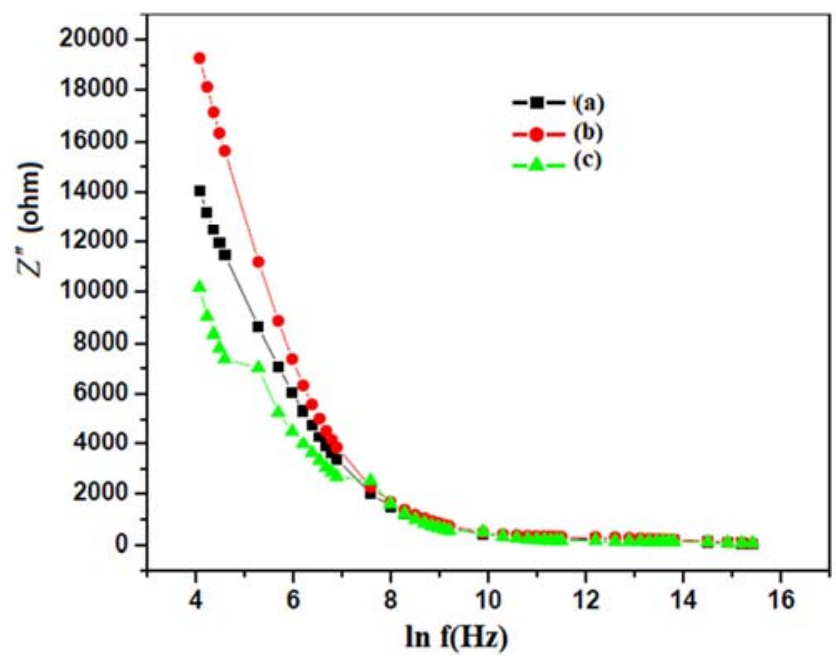

Figure 8. Imaginary impendence ( $\left.Z^{\prime \prime}\right)$ versus $\ln (f)$ for a) $\mathrm{LaMnO}_{3}$ b) $\left.\mathrm{La}_{0.8} \mathrm{Sr}_{0.1} \mathrm{Co}_{0.1} \mathrm{MnO}_{3-\delta} \mathrm{c}\right) \mathrm{La}_{0.8} \mathrm{Sr}_{0.1} \mathrm{Fe}_{0.1} \mathrm{MnO}_{3-\delta}$ of cathode materials.

The above Figure 8 shows the comparison of the imaginary impedance with the variation of the frequency. As the frequency increases, the amount of imaginary impedance decreases just like the real impedance. Unlike that of real impedance, the variation of frequency versus imaginary impedance is almost similar from logarithmic frequency of ' 8 ' and above for the three compounds. For lower 
logarithmic frequency below $6 \mathrm{~Hz}$, the imaginary impedance of $\mathrm{La}_{0.8} \mathrm{Sr}_{0.1} \mathrm{Co}_{0.1} \mathrm{MnO}_{3-\delta}$ greater than $\mathrm{LaMnO}_{3}$, $\mathrm{La}_{0.8} \mathrm{Sr}_{0.1} \mathrm{Fe}_{0.1} \mathrm{MnO}_{3-\delta}$. The decrease in imaginary impedance of the synthesized material $\mathrm{LaMnO}_{3}$ is nearly similar to the compound $\mathrm{La}_{0.8} \mathrm{Sr}_{0.1} \mathrm{Fe}_{0.1} \mathrm{MnO}_{3-\delta}$.

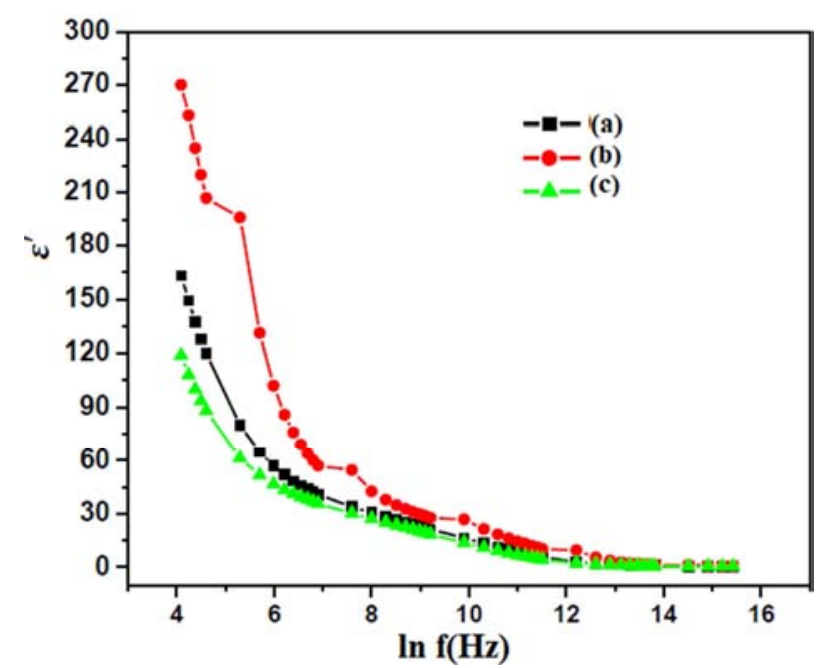

Figure 9. The variation of dielectric constant $\boldsymbol{\varepsilon}^{\prime}$ with frequency for a) $\mathrm{LaMnO}_{3}$ b) $\mathrm{La}_{0.8} \mathrm{Sr}_{0.1} \mathrm{Co}_{0.1} \mathrm{MnO}_{3-\delta}$ c) $\mathrm{La}_{0.8} \mathrm{Sr}_{0.1} \mathrm{Fe}_{0.1} \mathrm{MnO}_{3-\delta}$ of cathode materials.

The variation of dielectric constant $\boldsymbol{\varepsilon}^{\prime}$ with frequency was recorded for the compound. Figure 9 shows this variation with frequency on the $\mathrm{x}$-axis and dielectric constant on the $\mathrm{y}$ axis. As the frequency increases the dielectric constant decreases for the compound. Specifically, at around logarithmic frequency of $5 \mathrm{~Hz} \mathrm{La} \mathrm{La}_{0.8} \mathrm{Sr}_{0.1} \mathrm{Co}_{0.1} \mathrm{MnO}_{3}$ compound has a larger dielectric constant than $\mathrm{LaMnO}_{3}$ and $\mathrm{La}_{0.8} \mathrm{Sr}_{0.1} \mathrm{Fe}_{0.1} \mathrm{MnO}_{3-\delta}$ whereas the dielectric constant of $\mathrm{La}_{0.8} \mathrm{Sr}_{0.1} \mathrm{Fe}_{0.1} \mathrm{MnO}_{3-\delta}$ is the smallest. This implies that $\mathrm{La}_{0.8} \mathrm{Sr}_{0.1} \mathrm{Co}_{0.1} \mathrm{MnO}_{3-\delta}$ compound have more available polarization mechanisms as compared to the other compound synthesized for this research work. In general, as frequency increases, the material's net polarization drops as each polarization mechanism ceases to contribute, and hence its dielectric constant drops. In addition, the room temperature conductivity of all synthesized perovskite materials were calculated using equation and it is found to be $6.3 \times 10^{-3}$, $8.7 \times 10^{-3}$ and $5.8 \times 10^{-3} \mathrm{~S}$. $\mathrm{cm}^{-1}$ for $\mathrm{LaMnO}_{3}$, $\mathrm{La}_{0.8} \mathrm{Sr}_{0.1} \mathrm{Co}_{0.1} \mathrm{MnO}_{3-\delta}$ and $\mathrm{La}_{0.8} \mathrm{Sr}_{0.1} \mathrm{Fe}_{0.1} \mathrm{MnO}_{3-\delta}$ of cathode materials, respectively.

\section{Conclusions}

The overall performance of solid oxide fuel cell depends up on its cathode material. The compositions of the material, synthesis method have significant impact on the cathode material of SOFC. The result of DTG shows that the synthesized $\mathrm{LaMnO}_{3}$ materials have both endothermic and exothermic peak with the irrespective temperature. The TGA result of the compound shows the minimum calcination temperature which is $1000^{\circ} \mathrm{C}$. The structural property was investigated by using XRD. The result obtained from XRD for the three materials indicates that the lattice constant of $\mathrm{La}_{0.8} \mathrm{Sr}_{0.1} \mathrm{Fe}_{0.1} \mathrm{MnO}_{3-\delta}$ was larger than the other two but the crystal size was less than the other two materials. The unit cell volume of $\mathrm{LaMnO}_{3}$ material was less than the other two. The SEM was helpful in differentiating the morphology of the synthesized materials. For the material agglomerations can easily be observed in their SEM image. In combination with this the EDS shows the presence of each elements in each compound and the pure formation of the compound. The result from FTIR shows the three most absorption bands. These most significant absorption bands are located between 712.6 and $484.4 \mathrm{~cm}^{-1}$ wave numbers. In addition, the electrical and electrochemical property was reveled by using LCR measurement. Hence, the conductivities of the synthesized material is $6.3 \times 10^{-3}$.

\section{Acknowledgements}

A portion of this work was performed at the universities of Andhra, Arba Minch University and Adama University department of Materials Science and engineering and the authors thank the staff and scientists there such as Mr. Demeke, Dr. Paulos Shibeshy, Dr. Vije Babu and Dr. Satiham Bhuan for their time and assistance.

\section{References}

[1] Armaroli, N., \& Balzani, V. (2007). The future of energy supply: challenges and opportunities. Angewandte Chemie International Edition, 46 (1-2), 52-66.

[2] Trimm, D. L. (2005). Minimisation of carbon monoxide in a hydrogen stream for fuel cell application. Applied Catalysis A: General, 296 (1), 1-11.

[3] Park, J. H., Kim, S., \& Bard, A. J. (2006). Novel carbon doped $\mathrm{TiO}_{2}$ nano tube arrays with high aspect ratios for efficient solar water splitting. Nano letters, 6 (1), 24-28.

[4] Tarragó, D. P., Moreno, B., Chinarro, E., \& deSousa, V. C. (2016). Perovskites used in fuel cells. In Perovskite Materials-Synthesis, Characterisation, Properties, and Applications. In Tech.

[5] Levy, M. R. (2005). Tesis Doctoral Departamento de Materiales (Universidad deLandres).

[6] Hernández, E., Sagredo, V., \& Delgado, G. E. (2015). Synthesis and magnetic characterization of $\mathrm{LaMnO}_{3}$ nanoparticles. Revistamexican a defísica, 61 (3), 166-169.

[7] Varshney, D., \& Kaurav, N. (2004). Analysis of low temperature specific heat in the ferromagnetic state of the Cadoped manganites. The European Physical Journal BCondensed Matter and Complex Systems, 37 (3), 301-309.

[8] Batdemberel, G., Bulgan, G., Dinnebier, R. E., Munkhbaatar, P., Sangaa, D., \& Chadraabal, S. (2010, October). Rietveldrefinement of nano structural $\mathrm{LaMnO}_{3+\delta}$ perovskitetype manganite. In Strategic Technology (IFOST), 2010 International Forumon (pp.256-258). IEEE.

[9] Jnr, M. H., \& Spiff, A. I. (2005). Equilibriumsorption study of $\mathrm{Al}^{3+}, \mathrm{Co}^{2+}$ and $\mathrm{Ag}^{+}$in aqueous solutions by fluted pumpkin (Telfairiaoccidental is HOOKf) was tebiomass. Acta Chim. Slov, 52, 174-181. 
[10] Gaudry, E., Kiratisin, A., Sainctavit, P., Brouder, C., Mauri, F., Ramos, A.,... \& Goulon, J. (2005). X-ray (natural linear dichroism XNLD) applied to the determination of relaxations around transition metal impurities in $\alpha-\mathrm{Al}_{2} \mathrm{O}_{3}$. Physica Scripta, 2005 (T115), 1041.

[11] Yogamalar, R., Srinivasan, R., Vinu, A., Ariga, K., \& Bose, A. C. (2009). X-ray peak broadening analysis in $\mathrm{ZnO}$ nano particles. Solid State Communications, 149 (43-44), 19191923.

[12] Erdenee, N., Enkhnaran, U., Galsan, S., \& Pagvajav, A. (2017). Lanthanum-Based Perovskite-Type Oxides $\mathrm{La}_{1-\mathrm{x}} \mathrm{Ce}_{\mathrm{x}} \mathrm{BO}_{3}(\mathrm{~B}=\mathrm{Mn}$ and $\mathrm{Co})$ as Catalysts: Synthesis and Characterization. Journal of Nano materials, 2017.
[13] Macdonald, J. R., \& Barsoukov, E. (2005). Impedance spectroscopy: theory, experiment, and applications. History, 1 (8).

[14] Hussain, A. M., Pan, K. J., Robinson, I. A., Hays, T., \& Wachsman, E. D. (2016). Stannate-based ceramic oxide as anode materials for oxide-ion conducting low-temperature solid oxide fuel cells. Journal of The Electrochemical Society, 163 (10), F1198-F1205. 